\title{
Incidence of internal parasites of the slaughtered local breeds of ducks and geese
}

\author{
B.Y. Al-Lahaibi ${ }^{\circledR}$, M.H. Hasan ${ }^{\circledR}$ and A.F. Al-Taee \\ Department of Microbiology, College of Veterinary Medicine, University of Mosul, Mosul, Iraq
}

\section{Article information}

Article history:

Received October 28, 2019

Accepted January 20, 2020

Available online September 11, 2020

Keywords:

Internal parasites

Ducks

Geese

\begin{abstract}
This study was carried out to determine the presence of gastrointestinal parasites of local ducks and geese in Nineveh province. Sixty-four ducks and seventy geese of different ages and sexes were purchased from local markets. Necropsy findings in ducks reviled a total infection rate of $68.8 \%$ was with protozoa, $50 \%$ was with nematodes, while $28.1 \%$ were with cestodes. On the other hand, in geese, the percentages with the mentioned parasites were $78.6 \%$ with protozoa, $54.2 \%$ with nematodes, $31.4 \%$ with cestodes. Four types of nematodes were identified in ducks; Ascaridia galli, Heterakis gallinarum, Heterakis isolonche, and Subulura brompti, the same were also found in geese except Heterakis.isolonche. Cestodes identified in ducks and geese were Railletina tetragona, Railletina echinobothrda, Railletina cesticillus and Coantaenia infundibulum. The detected protozoa include Eimeria spp., Tyzeria spp., Wenyonella spp., Cryptosporidia spp., Giardia spp. Double infection with parasite was higher in ducks while the triple infection in geese was the higher.
\end{abstract}

DOI: 10.33899/ijvs.2020.126242.1272, @2021, College of Veterinary Medicine, University of Mosul.

This is an open access article under the CC BY 4.0 license (http://creativecommons.org/licenses/by/4.0/).

\section{Introduction}

In Iraq, ducks and geese are often raised in cities as home-grown, also in villages and rural areas, as they constitute important proportions of per capita income and to benefit from their meat, eggs and feathers, the intensive breeding of ducks and geese is always associated with parasitic infections (1). Internal parasites, including worms and protozoa, are common in poultry because they are grown outside homes and so exposed to soil that is a source of infection. Worm infection is also associated with unthriftiness and poor growth, low eggs production, low percentage of fertilization and mortalities especially in acute cases, the presence of intermediate host and victors in the vicinity of poultry breeding locations, such as beetles, ants, and houseflies are responsible for the transmission and persistence of parasitic infection $(2,3)$. Several studies have been conducted in Iraq and Nineveh governorate on the presence and prevalence of internal parasites in ducks and geese (4-7).

For further studies this research was carried out on ducks and geese delivered from different regions of Nineveh province on the postmortem status to identify the different stages of gastrointestinal tract helminthes and protozoa.

\section{Materials and methods}

This study conducted from April 2017 to December 2018, included several regions in Nineveh province including city center, Kokgali, Hamdania, Bazwaya, Khazer, Salamia and Tizkharab bartela, Talkeef. One hundred forty-three, 64 ducks and 70 geese, with different ages (from 5 months to more than one year) and sexes from question the owners, were purchased from local markets and from their owners. These birds were reared with healthy and sick chickens showing emaciation, weight loss and 
weakness. Necropsy was done according to (8) after slaughtering of the delivered ducks and geese to the laboratory of parasitology, Department of Microbiology, College of Veterinary Medicine, University of Mosul. All gastrointestinal tracts were partitioned to their segments of crop, proventriculus, gizzard small intestine and caecum Mucosal scraping was done to each separated segments. Parasitic examination methods of direct, flotation and sedimentation techniques were carried out according to (911) to elucidate any parasites or their eggs and oocytes, under light microscopes. The gastrointestinal parasites prevalence rate and mean intensity were calculated according to (12).

\section{Results}

Among 64 ducks screened, 48 were found positive for gastrointestinal parasites and among 70 gees screened, 41 were found positive for parasites (Table 1).

Out of 48 infected ducks, 32(50\%) were found positive for nematoda, $18(7.28 \%)$ were positive for cestoda and $44(68.8 \%)$ were infected with protozoa (Table 2$)$.

While out of 41 infected geese, 38(54.2\%) were found positive for nematoda, $22(31.4 \%)$ positive for cestoda and $55(78.6 \%)$ were infected with protozoa (Table 3 ).

At necropsy, four species of Nematodes are found in ducks, and they were Ascaridia galli, Heterakis gallinarum,
Heterakis isolonche, Subulura brompti with intensity of 1.3, 2.6, 2.5, and 1.4 respectively (Table 4) (Figures 1-4).

Table 1: Total Prevalence rate of internal parasites in duck and gees in Mosul city

\begin{tabular}{lccc}
\hline Birds & No. of examine & No. of infected & $\%$ \\
\hline Ducks & 64 & 48 & 75 \\
Geese & 70 & 41 & 58.6 \\
\hline
\end{tabular}

Table 2: Prevalence rate of internal parasites in ducks

\begin{tabular}{lcc}
\hline Parasites & No. of infected & $\%$ \\
\hline Nematodes & 32 & $50 \%$ \\
Cestoda & 18 & $28.1 \%$ \\
Protozoa & 44 & $68.8 \%$ \\
\hline Total & 94 & \\
\hline
\end{tabular}

Table 3: Prevalence rate of internal parasites in geese

\begin{tabular}{lcc}
\hline Parasites & No. of infected & $\%$ \\
\hline Nematodes & 38 & $54.2 \%$ \\
Cestoda & 22 & $31.4 \%$ \\
Protozoa & 55 & $78.6 \%$ \\
\hline Total & 115 & \\
\hline
\end{tabular}

Table 4: Intensity of adult helminthes nematodes in ducks

\begin{tabular}{lcccc}
\hline Site of recovery & Helminth & No. of infected birds & No. of parasites & Mean of intensity \\
\hline Small intestine & Ascaridia galli & 32 & 42 & 1.3 \\
Caecum & Heterakis gallinarum & 20 & 52 & 2.6 \\
Caecum & Heterakis isolonche & 4 & 10 & 2.5 \\
Caecum & Subulura brompti & 18 & 26 & 1.4 \\
\hline
\end{tabular}

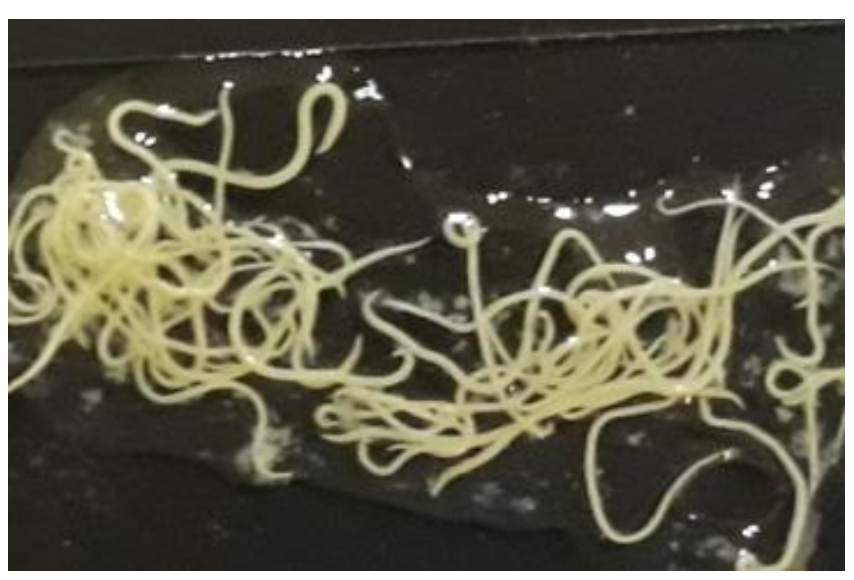

Figure 1: Duck intestinal contents showing nematode parasites.
In comparison to the geese, which revealed three species of Nematodes Ascaridia galli, Heterakis gallinarum, Subulura brompti with intensity 1.2, 1.3, and 1.6 respectively. At scraping of the gastrointestinal tract five types of eggs were identified including Ascaridia galli, Heterakis. gallinarum, Subulura brompti, Capillaria spp. and Syngamus trachea (Table 5) (Figure 5).

It is interesting to note that it was the first time in which Heterakis isolonche was recorded in the caecum of ducks in Mosul city. These worms were small white worms, with 3 prominent lips on the mouth and well developed esophageal bulb, they were differentiated from Heterakis. gallinarum as the end of male worms had equal spicules (Figure 4) while the posterior end of the male of Heterakis gallinarum possesses prominent circular pre- cloacal sucker and has two unequal spicules (Figure 3). 


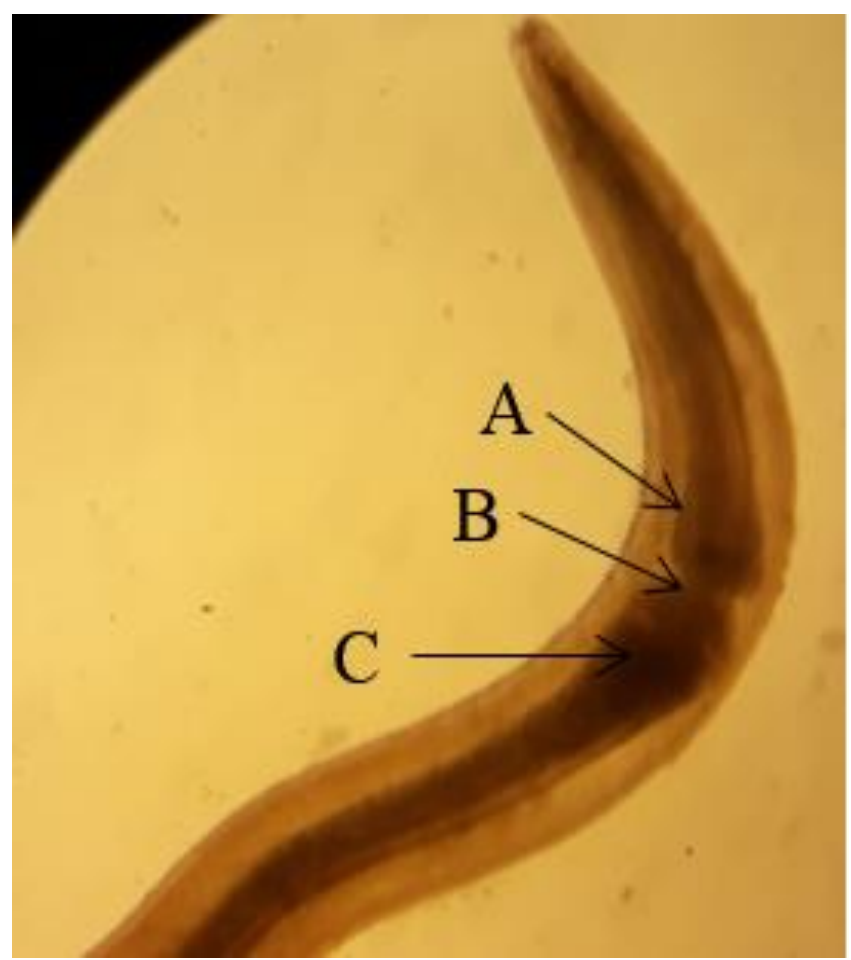

Figure 2: Anterior end of Subulura brumpti from the cecum of ducks, with a small swelling (A) followed by a constriction (B) and an esophageal bulb (C). x10.

In ducks the types of infection either with one or more parasites recorded in this study (Table 6) showed that the higher percentage was traced to the double type of infection $37.5 \%$, then by the triple type of infection $33.3 \%$ followed by the single type of infection $25 \%$ while the lowest one was the quadruple type $4.1 \%$.

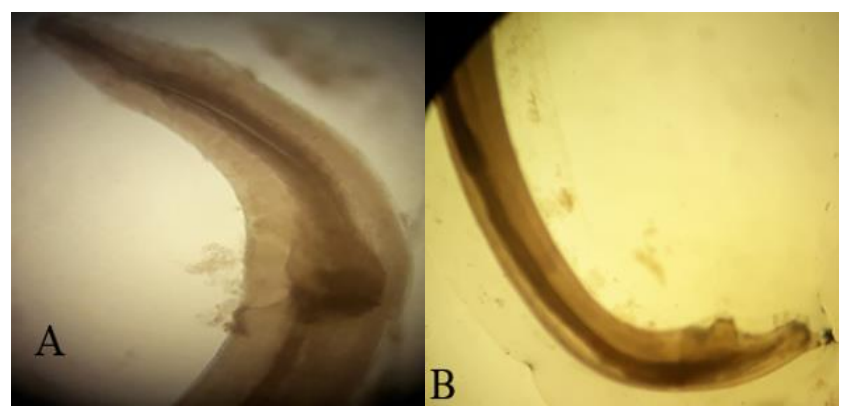

Figure 3: Anterior end (A) and Posterior end (B) of Heterakis gallinarum of cecal scrapping of a duck showing male worm with two unequal spicules. x10.

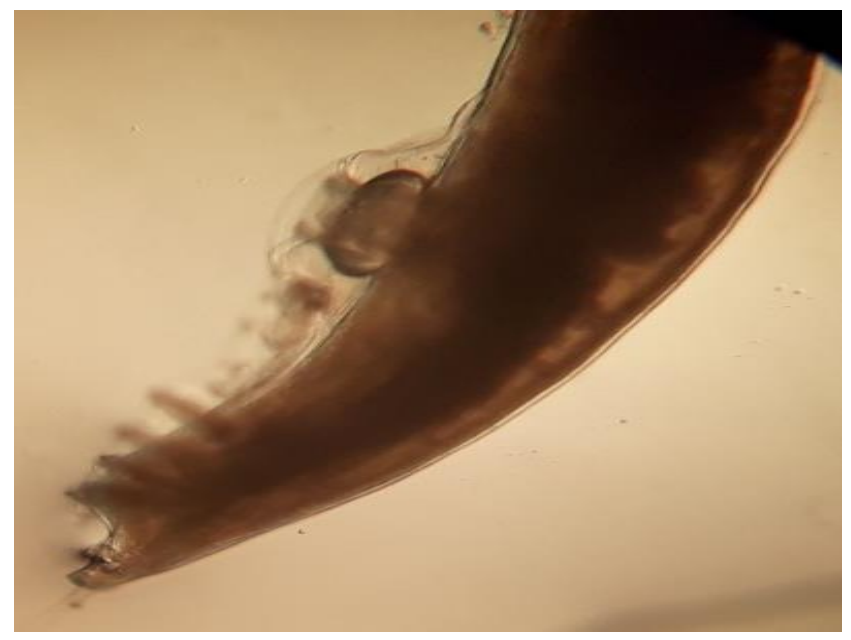

Figure 4: Posterior end of Heterakis isolonche of cecal scrapping of a duck showing male worm with equal spicules. $x 10$.

Table 5: Intensity of adult helminth nematodes in geese

\begin{tabular}{lcccc}
\hline Site of recovery & Helminth & No. of infected birds & No. of parasites & Mean of intensity \\
\hline Small intestine & Ascaridia galli & 18 & 22 & 1.2 \\
Caecum & Heterakis gallinarum & 24 & 32 & 1.3 \\
Caecum & Subulura brompti & 11 & 18 & 1.6 \\
\hline
\end{tabular}
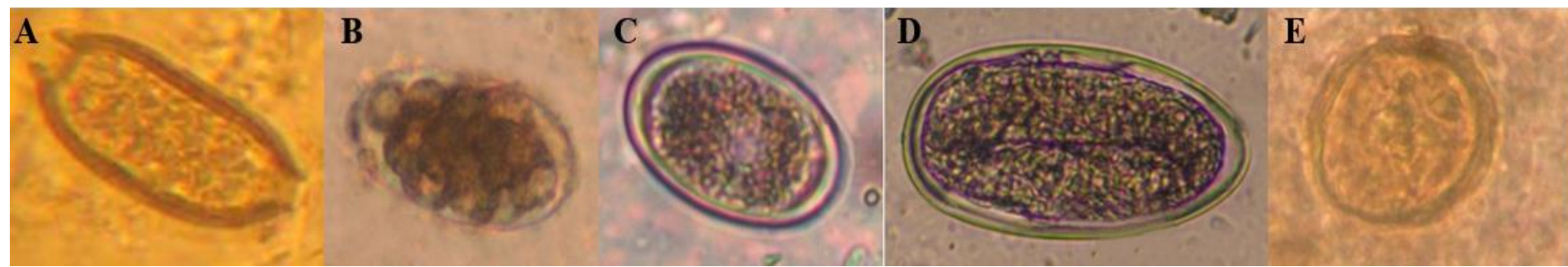

Figure 5: Different nematode eggs in gastrointestinal scraping, x10. (A) Egg of Capillaria spp, (B) Egg of Syngamus trachea, (C) Egg of Heterakis gallinarum, (D) Egg of Subulura brumpti, (E) Egg of Ascaridia galli. 
Table 6: Prevalence rate of internal parasites in ducks according to type infection

\begin{tabular}{lcc}
\hline Type of infection & No. of infected & $\%$ \\
\hline Single & 12 & $25 \%$ \\
Double & 18 & $37.5 \%$ \\
Triple & 16 & $33.3 \%$ \\
Quadruple & 2 & $4.1 \%$ \\
\hline Total & 48 & $75 \%$ \\
\hline
\end{tabular}

In gees (Table 7) shows that the triple infection was the highest one with a percentage of $41.4 \%$, then the single type $24.3 \%$ while the double type of infection $22.2 \%$ and the lowest one was the quadruple $4.8 \%$.

Table 7: Prevalence rate of internal parasite in geese according the type of infection

\begin{tabular}{lcc}
\hline Type of infection & No. of infected & $\%$ \\
\hline Single & 10 & $24.3 \%$ \\
Double & 12 & $22.2 \%$ \\
Triple & 17 & $41.4 \%$ \\
Quadruple & 2 & $4.8 \%$ \\
\hline Total & 41 & $58.6 \%$ \\
\hline
\end{tabular}

\section{Discussion}

Internal parasitic infection are of great importance in breeding birds, especially ducks and geese in terms of their nature, nutrition, presence close to ponds and stagnant water since they are rearing in a backyard system so they could be exposed to eggs, larvae, intermediate hosts and vectors of many parasites in feces contaminating soil and water in addition to their poking and dipping feeding their waste and bedding, which may end in mortalities $(13,14)$, there for our necropsy findings done on 64 ducks and 70 geese for investigation of gastrointestinal parasitic infection, a total of $75 \%$ was recorded in ducks and $58.6 \%$. In geese. Our current results were lower than those recorded in the same province of Nineveh for ducks and geese, which were $86.25 \%$ (5), but higher than that recorded in Al-Diwaniya province of $47.5 \%$ (6). In world, the rate was $51.7 \%$ in Kenya (15) and $15.15 \%$ in China (16).

The results of this study showed that the mean of intensity of nematodes in ducks was $50 \%$ including four species namely Ascaridia galli 1.3\%; Heterakis gallinarum $2.6 \%$; Heterakis isolonche $2.5 \%$, Subulura brompti $1.4 \%$, and $54.2 \%$ in geese with the same species as above except Heterakis isolonche, with mean of intensity of 1.2, 1.3, and 1.6 respectively.

The percentage of cestode infections were $28.1 \%$ and $31.4 \%$ in ducks and geese, respectively, and only two types of cestodes were identified here namely with the mean of intensity Railletina spp. and Coantaenia spp.
In comparison with the previous study performed by (5) about the infection with the internal parasites of ducks and geese in Nineveh province, they recorded 11 species of nematodes in ducks, including Ascaridia galli and Heterakis spp. Sublura spp. while in geese, 7 species were recorded, including Ascaridia galli, Heterakis spp., and Sublura brumpti., and four types of cestodes including Railletina spp. Nearly similar percentage were recorded by (17) and but lowered than that recorded by (18).

In southern Iraq, Al-Diwaniya province (19) found that the infection rate in ducks with nematodes was $82.71 \%$, and 96.29\% with cestodes, and within the same category (6), reported $47.5 \%$ of internal parasites. In Al-Najaf (20) found lesser nematodes infection in chickens with a rate of $47.8 \%$ including Ascaridia galli, Heterakis spp. and Capillaria spp.

In Bangladesh, 167 of the ducks examined, (81.1\%) were infected by one/more species of gastro-intestinal helminthes, with a total of ten species of helminth parasites were recovered from gastrointestinal tract, of which four species were trematodes (21), but (22) in Gilan province/ Iran, estimated a higher rate of infection reaching $50 \%$ including Railletina tetragona, Heterakis gallinarum, Capillaria spp.

In Bangladesh (23) estimated infection rate of $80 \%$ in ducks with intestinal nematodes, and an intensity of $24.4 \%$ and $15.33 \%$ in females and males respectively. In the same country (24) recorded a high percentage with helminthes reached $98.33 \%$, of which 16 types trematodes, 8 cestodes and 5 nematodes.

In cases of massive infestation, one can observe growth retardation, diarrhea and/or anemia and immunosuppression (25). Ascaridia galli can cause enteritis, weight loss, anemia and even nervous signs. A heavy infestation may cause an intestinal obstruction (25). This finding could be attributed to the higher fecundity of female worm (26).

From above, it is clear that there is a huge difference in the percentages of intestinal parasitic infections and their types. These differences may be attributed to the rearing systems of ducks and geese in different geographical areas and the specificity of climatic changes in these locations regarding rainfall, drought, humidity and temperature. The type of management and breeding system play also a pivotal role in the transmission of infections between different types of birds when breeding them in a backyard mixing system, in addition to the adding extrinsic parasitic infections from the migratory birds. The role of age, gender, nutrition, health and immune status of the host cannot be overlooked $(14,20,27,28)$.

Internal parasitic infections, including intestinal ones have a great negative impact on meat and egg production, health parameters and immune status of the infected birds, which increase or predispose them to other infections in spite of parasites themselves being an important etiological causes of different diseases (28-30). 
In our study, the total infection rate of protozoa in ducks was $68.8 \%$, including Eimeria spp., Tyzeria spp., Wenyonella spp., Cryptosporidia spp., Giardia spp. The same species were found also in geese but at a higher percentage of $78.6 \%$.

Comparing with other studies in ducks performed in Nineveh province (31) recorded a percentage of $77 \%$ for Cryptosporidia spp. and $63.75 \%$ with Eimeria spp. and Tyzeria spp. (4), while in geese the percentage rate with Cryptosporidia spp. was $46.67 \%$. (32), and $34.4 \%$ and $36.45 \%$ in ducks and geese with Giardia spp. respectively. In the south of Iraq, Al- Al-Diwaniya province (6), recorded infection rate of $11.25 \%$ with Eimeria spp. in ducks. Outside Iraq (in New Mexico), Giardia spp. infection in geese were recorded at a rate of $28 \%$ (14). While inside Iraq they were $29.4 \%$ (6) and $28 \%$ in New Mexico (14).

The possible causes for infection with different types of protozoa in ducks and geese could be attributed to various etiological cause of these are poor management, lack of hygienic conditions, overcrowding, presence of insects and rodents, outside contamination from migrating or wild birds, mixed breeding with other types of birds, the location of birds rearing, their environmental conditions like the effect of season an diurnal temperatures in addition to the individual variations between them with their different physiological and immunological status.

The negative impact with protozoan infection on the health and productivity of ducks and geese comes from the emaciation with Cryptosporidia spp. (33), low production efficiency with Wenyonella philiplevinei $(6,34)$, hemorrhagic enteritis with Tyzeria spp. especially in young birds (35), and coccidia $(25,36,37)$. Reduction of food absorption and dryness of the skin with Giardia spp. infection (32).

Other parasites like cestodes have also been reported to cause massive infection in ducks represented by diarrhea, anemia and growth retardation; the upper part of the digestive system was also claimed to be affected by nematodes especially by capillariosis causing dysphagia and local inflammation in the crop and esophagus; ascaridiosis and heterakidosis are also another threats to ducks and geese causing enteritis, weight loss, anemia, nervous signs and intestinal obstruction (25).

Tizzeria perniciosa is pathogenic because of its deeper penetration into the intestinal mucosa of common ducklings less than four weeks old. Hemorrhagic enteritis can occur with a mortality rate of $70 \%$. Eimeria mulardi is also pathogenic for ducks.

\section{Conclusion}

This study was conducted to determine internal parasites in local ducks and geese in Nineveh province. A total Prevalence rate of internal parasites (nematodes, cestodes, protozoa) was $75 \%$ and $58.6 \%$ in ducks and geese respectively.

\section{Acknowledgments}

The authors are very grateful to the University of Mosul, College of Veterinary Medicine for their provided facilities, which helped to improve the quality of this work.

\section{Conflict of Interest}

The authors declare that no conflict of interests of the manuscript.

\section{References}

1. Amundson CL, Traub NJ, Smith-Herron AJ, Flint PL. Helminth community structure in two species of arctic-breeding waterfowl. Inter J Parasitol. 2016;5(3):263-272. Doi: 10.1016/j.ijppaw.2016.09.002

2. Phiri IK, Phiri AM, Zeila M, Chota A, Masuku M, Monrad J. Prevalence and distribution of gastrointestinal helminths and their effects on weight gain in free-range chickens in central Zambia. Trop Anim Heal Prod. 2007;39:309-315.Doi: 10.1007/s11250-007-9021-5

3. Mebrahtu A, Berhanu M, Abrha B, Gebretsadik A. Gastrointestinal helminth parasites of chicken under different management system in Mekelle town, Tigray region, Ethiopia. Res Arciv. 2019;1307582;1-7. Doi: $10.1155 / 2019 / 1307582$

4. Abdulla DA. Coccidiosis in domesticated duck in Nineveh governorate. Iraqi J Vet Sci. 2010;24(2):93-97. Doi: 10.33899/ijvs.2010.5602

5. Al-Taee AF, Mohammed RG, Mohammed NH. Diagnosis of some helminthic eggs in faces of ducks and geese in Nineveh governorate, Iraq. Iraqi J Vet Sci. 2011;25(1):5-10. Doi: 10.33899/ijvs.2011.5696

6. Al-Labban NQ. Isolation and identification of some parasites in local ducks and their pathological changes in Al-Diwaniya province [master's thesis]. Al-Qaadisiya : College of Veterinary Medicine, AlQadisiya University; 2012.90 p.

7. Mohammed NH. Study on the blood protozoa in geese. Iraqi J Vet Sci. 2020;34(1):23-27. Doi: 10.33899/ijvs.2019.125499.1028

8. Islam MR, Shaikh H, Baki MA. Prevalence and pathology of helminth parasites in domestic ducks of Bangladesh. Vet Parasitol. 1988;29(1):73-77. Doi: 10.1016/0304-4017(88)90009-X

9. Afia UU, Usip LP, Udoaka UE. Prevalence of gastro-intestinal helminths in local and broiler chickens in Ibesikpo local government area, Akwa Ibom State, Nigeria. Am J Zool Res. 2019;7(1):1-7. Doi: 10.12691/ajzr-7-1-1

10. Amundson CL, Traub NJ, Smith-Herron AJ, Flint PL. Helminth community structure in two species of arctic-breeding waterfowl. Inter J Parasitol. 2016;5(3):263-272. Doi: 10.1016/j.ijppaw.2016.09.002

11. Mohammad RY, Seyed HH, Amir HAT, Hadi AA, Farshid JR. Gastrointestinal helminthes of green-winged teal (Anas crecca) from north Iran. Asian Pac J Trop Biomed. 2014;4(1):S143S147.Doi: 10.12980/APJTB.4.2014C1205.

12. Mohammad Z.A. Some chewing lice (Phthiraptera) species as ectoparasites infested aquatic birds with a new record of three species from Al-Sanaf marsh/ southern Iraq. Iraqi J Vet Sci. 2020;34(1):173180. DOI: $10.33899 /$ ijvs.2019.125721.1139

13. Al-Gabery KM. Diagnostic and pathological study of cestodes in intestine of three types of pigeon in Najaf province [master's thesis]. Kufa: College of Education, Al-Kufa University; 2006. 12 p.

14. Hoberge EP, Lioy D, Omar H. Libyostrongylus dentatus n. sp (Nematode: trichostrongylidae) from ostriches in north America with comment on the genera Libyostrongylus and Paralibyostougylus. J 
Parasitol. 1995;81:85-93. Doi: 10.2307/3284011

15. Waruiru RM, Mavati SK, Mbuthia PG, Njagi LW. Prevalence and intensity of gastro- intestinal helminth infestation of free range domestic ducks in Kenya. Livestock Res Rural Develop. 2018;30(4):18-25. Doi: 10.1080/23144599.2019.1708577

16. Wang XQ, Lin RQ, Zhu X Q. Prevalence of intestinal helminths in domestic goose (Anser domesticus) in Qingyuan, Guangdong province, China. Afri J Microbiol Res. 2013;40(6):43-46. Doi: 10.5897/ajmr12.706

17. Kuhn RC, Rock CM, Oshima KH. Occurrence of Cryptosporidium and Giardia in wild ducks along the Rio Grande River Valley in southern New Mexico. Appl Environ Microbiol. 2002;68(1):161-165. Doi: 10.1128/AEM.68.1.161-165.2002

18. Farjana T, Islam KR, Mondal MH. Population density of helminths in ducks: effects of host's age, sex, breed and season. Bangl J Vet Med. 2008;6(1):45-51. Doi: 10.3329/bjvm.v6i1.1338

19. Shubber HW. The parasitic helminthes of the digestive tract of the ducks Netta rufina and Anas cerca [master's thesis]. Al-Qadisya: College of Education, University of Al-Qadisya; 2006. 122 p.

20. Muhsin SJ. Epidemiological and pathological study of Ascardia galli in Najaf governorate [PhD dissertation]. Kufa: College of Education for Girls. University of Al- Kufa; 2008. 110 p.

21. Yousuf M, Das P, Anisuzzaman M, Banowary B. Gastro-intestinal helminths of ducks: Some epidemiologic and pathologic aspects. J Bangladesh Agri Uni. 1970;7(1):91-7. Doi: 10.3329/jbau.v7i1

22. Shemshadi B, Ranjbar B, Delfan AM. Prevalence and intensity of parasitic infection in domestic ducks (Anas platyrhyuchus) in Gilan province, northern Iran. Comp Clin Pathol. 2016:1-3. Doi: 10.1007/s00580-0016-2361-7

23. Sharmin M, Tania R, Hamied K. Prevalence and intensity of parasites in domestic ducks. Dhaka Uni J Biol Sci. 2012;21(2):197-199. Doi: 10.3329/dujbs.v21i2.11518

24. Anisuzzaman MA, Rajman MH, Mondal MM. Helminth parasites in indogenous duck L: Seasonal dynamic and effect on production performance. J Bang Agr Univ. 2005;3(2):291-295. Doi: 10.22004/ag.econ.276489

25. Nnadi PA, George SO. A Cross- sectional survey on parasites of chickens in selected villages in the subhumid zones of south-eastern Nigeria. J Parasitol Res. 2010;141824. Doi: 10.1155/2010/141824

26. Berhe M, Mekibib B, Bsrat A, Atsbaha G. Gastrointestinal helminth parasites of chicken under different management system in Mekelle town, Tigray region, Ethiopia, J Vet Med. 2019;7(1):31-37. Doi: 10.1155/2019/1307582

27. Slimane BB. Prevalence of the gastro-intestinal parasites of domestic chicken Gallus domesticus Linnaeus, 1758 in Tunisia according to the agro-ecological zones. J Parasit Dis. 2016;40(3):774-778. Doi: $10.1007 / \mathrm{s} 12639-014-0577-5$

28. Ola-Fadunsin SD, Uwabujo PI, Sanda IM, Ganiyu IA, Hussain K, Rabiu M. Gastrointestinal helminths of intensively managed poultry in Kwara Central, Kwara State, Nigeria: Its diversity, prevalence, intensity, and risk factors. Vet World. 2019;12(3):389-96. Doi: 10.14202/vetworld.2019.389-396

29. Tolossa Y, Basu A, Shafi Z. Ectoparasites and gastrointestinal helminths of chickens of three agro-climatic zones in Oromia Region, Ethiopia. Anim Biol. 2009;59(3):289-97. Doi: 10.1163/157075609x454926

30. Silva G da, Romera D, Fonseca L, Meireles M. Helminthic Parasites of Chickens (Gallus domesticus) in different regions of São Paulo State, Brazil. Revista Brasileira de Ciência Avícola. 2016;18(1):1638. Doi: $10.1590 / 18069061-2015-0122$

31. Mohammed NH. Detection of Cryptosporidium spp. In feces of ducks in Nineveh governorate. Iraqi J Vet Sci. 2009;23(1):1-5. Doi: 10.33899/ijvs.2009.5689

32. Mohammed NH. Prevalence of Giardia spp. in ducks and geese in
Nineveh governorate. Iraqi J Vet Sci. 2009;23(1):1-5. Doi: 10. 338999/ijvs.2012.35197

33. Richter D, Wieganl TG, Burkher DT, Kaleta EF. Natural infection by Cryptospordium sp. in farm: Raised ducks and geese. Avian Pathol. 1994;23(2):277-286. Doi: 10.1080/03079459408418995

34. Al-Labban NQ, Dowood KH, Jassem GA. New parasites of local duck recorded in Iraq with histopathological study. Al-Qadisiyah J Vet Med Sci. 2013;12(1):152-161. Doi: 10.29079/vol12iss1art244

35. Chung OS, Lee HJ, Sohu WM, Park YK, Chai JY, Seo M. Discovery of Parvatrema duboisi and Parvatrema homoeotecnum (Digenea: Gymnophallidae) from migratory birds in Korean. J Parasitol. 2010;48(3):271-274. Doi: 10.3347/kjp.2010.48.3.271

36. Chauve C. The poultry red mite Dermanyssus gallinae (De Geer,1778): Current situation and future prospects for control. Vet Parasitol. 1998;79:239-245. Doi: 10.1016/S0304-4017(98)00167-8

37. Alvin G, Gary W, Stockdale PG. Coccidia of domestic and wild waterfowl (Anseriformes). Canadian J Zool. 1983,61(1):1-24. DOI: $\underline{10.1139 / \mathrm{z} 83-001}$
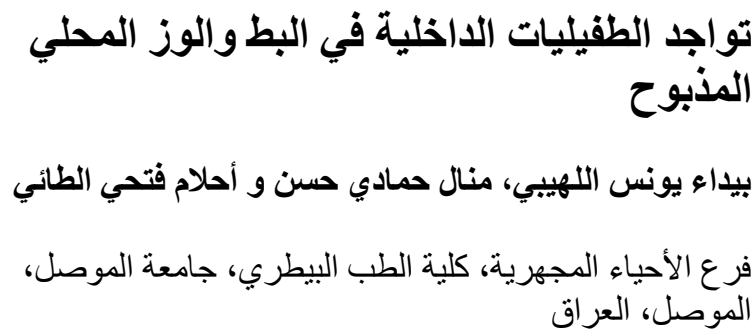

الخلاصة

أجريت هذه الدراسة لتحديد وجود الطفيليات المعدية المعوية للبط

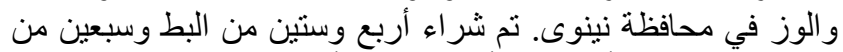

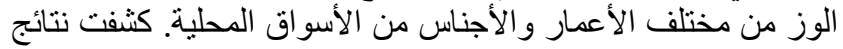

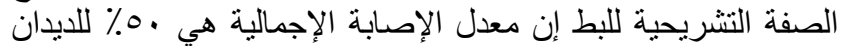

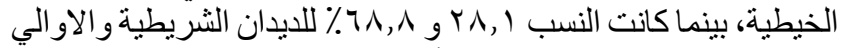

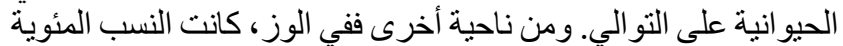

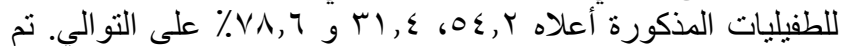

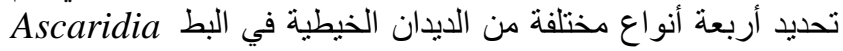
و Heterakis isolonche و Heterakis gallinarum galli في Subulura brompti

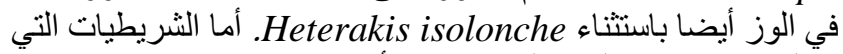
تم الكثف عنها في البطو الوز فكانت الأنواع Railletina tetragona Railletina cesticillus و Railletina echinobothrda و وكان و وكان معدل الإصابة الكلي للاو الي

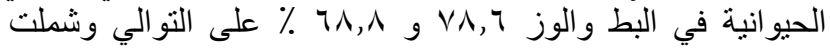
و Wenyonella spp. وTyzeria spp. وEimeria spp. Cryptosporidia spp.

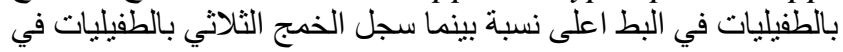

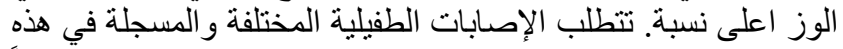

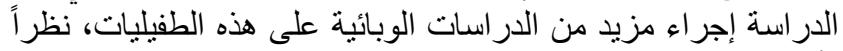
لأهميتها الاقتصادية و الصحية. 